\title{
INFORMATION TECHNOLOGY IMPACT ON HOTEL BUSINESS SUSTAINABILITY \\ "Bringing Best Practices to Improve the Hotel Performance"
}

\author{
Gihan Nabil Ahmed \\ Lecturer, Hotel Studies Department \\ Faculty of Tourism and Hotels, Sadat City University
}

\author{
Hany Atef Kouzmal \\ Lecturer, Hotel Studies Department \\ Higher Institute for Tourism and Hotels, EGOTH, Luxor
}

\begin{abstract}
With increased business and improved technology an Information Technology (IT) System became possible, and then IT became necessary to have a consistent method of tracking and maintaining business operations. Later, as customers' expectations changed, IT became necessary to ensure consistency of meeting customer needs. At a time of soaring energy costs and fragile financial markets, hotels managers are increasingly looking toward sustainability strategies to save money and to cut claims. Sustainability in any hotel can mean small adjustments or a major reorientation. There is no one size fits all approach to creating a sustainable hotel, but there are specific strategies that have had widespread success. These strategies can be implemented by IT to put the hotel industry on a more sustainable path. Worldwide, hotels are now using IT capabilities to facilitate sustainability. The aim of this study is to draw results that help in knowing the importance of using IT practices in sustaining the hotel business that increase its performance. It also seeks to develop IT to achieve wide range of sustainability that match with this century challenges needs

The data gathered revealed the following:

- Hotels use practices of information technology systems can get a high-quality performance that help in proper decision-making.

- There is a significant relation between the information technology practices and keeping the hotel business sustainable.

Based upon the findings of the investigated hotels the following recommendations could be suggested:

- Identification and implementation of IT practices can help in building a sustainable competitive advantage for hotels.

- IT is crucial in sharing information and empowering executives.

- Integrating IT globally in sustainability plans is a key in hotel performance.
\end{abstract}

Keyword: Information technology - Sustainability - IT practices -Management Performance. 


\section{Introduction}

The definition of technology system has attracted the attention of many authors, for example O'connor (2004) defined technology system as made up of several components, including hardware, software and the user, which work together to perform various tasks. Sing and kasavana (2005) defined technology system as the tool, kills and knowledge needed to process information electronically. While, Greasleyet al., (2006) mentioned that technology system consists of a number of interrelated components that work together. Moreover; According to the TEC terms of computer dictionary (2011) information technology is anything related to computing technology such as networking, hardware, software, internet and people dealing with technologies. Information Technology (IT) is the amalgamation of hardware, software, data, people and procedures that enables or inhibits business objectives depending on management's involvement in IT (Zadlo and Gray, 2014).Sustainability is a hotel's capacity to prosper in a competitive and changing global business environment by anticipating and managing current and future economic, environmental and social opportunities and risks. Hotels that address these factors through innovation, quality and productivity enhance their ability to generate long-term shareholder value (Bomba, 2014).

\section{Information Technology in Hotel Industry}

It can be noticed that the definitions of the technology system focused on both hardware and software components. Several researchers (e.g. O'Connor, 2004; Tesone, 2007; Miller et al., 2007) agreed that the hotel industry has identified effective implementation of IT as a vital component of the effort to promote and achieve its goals for successful description, promotion, distribution and delivery of hotel products and services. Singh and Kasavana (2005) argued that hotels have been slow adopters of new technology as compared with other service industries. Moreover; Lee et al., (2006) argued that IT is a general term used to describe technologies that help produce, manipulate, store, or communicate information. In addition; Chathoth (2007) agreed with Kasavana that hotels have been slow to implement new technology since the average firm in the industry has implemented new based-technology products and services several years after the technology was first introduced to the market. Tesone (2007) said that the hotel industry, particularly full-service hotel firms, has yet to fully accept IT Change to become more efficient in the service production functions. Similarly, Edward (2007) said that IT is the capability offered by software, hardware, and telecommunication networks to deliver data in different forms to individual and organizations.

\section{Sustainability in Hotels}

Hotels believe in their staff, culture and ability to deliver value to all of stakeholders. Like uncompromising integrity and customer focus, being sustainable is part of their vision; strengths to achieve continued long-term success are committed to managing sustainability and strive to put the right people, pro cusses and partners in place to help us achieve their vision. Since hotels began a formal approach to sustainability, hotel have broadened and deepened efforts by embedding sustainability within operations and supply chain. Hotel extensive framework of policies and management systems is established and continues to evolve as face new challenges (Ball, 2014).

Also, corporate sustainability can make high hotel performance through: 
- Decision-making through a Sustainability lens supports long-term profitability

- A big goal of Corporate Sustainability is increased transparency.

- Sustainability is largely about managing risk and driving innovation, both of which are top priorities for most corporations

- Attract and retain top talent

Corporate Sustainability can drive innovation and efficiency and...ultimately, valuation (Bomba, 2014).

Furthermore, sustainability in hotels can achieve the following which increase its performance:-

- Enhance the services, value, satisfaction level and financial result of Hotels and Resorts.

- Continue to use efficient training program that already exist.

- Mmaintain staff loyalty by continually working as a team

- Iincentive programs

- promotions and room for growth within the company

- guest involvement

- increase employee morale and productivity

- Consider the local community, guests and other stakeholders in helping to sustain the community and environment (Riu Hotels and Resorts, 2014).

In general sustainability means the following: meeting the needs of the present without compromising the ability of future generations to meet their needs; More than "going green"; Includes employees, customers, community, and company reputation (Heizer and Render, 2014). While, sustainable development is development that meets the needs of the present without compromising the ability of future generations to meet their own needs (Longhurst, 2014).

In addition, Hopkins, (2014) assured that sustainable development is:

- Global Change (environment)

- Globalization (economic)

- Human Development (social/culture)

- Sustainable Development

\section{Sustainabilityand Performance Relation}

Bomba, (2014) linked the relation between sustainability and performance stated that:

1. Governance:

Corporate Governance, Risk Management, Codes of Conduct, Customer Relationship Management, Lobbying and Piracy.

\section{Environment:}

Environmental Reporting, Environmental Policy/ Management, Operational EcoEfficiency and Hazardous Substances

\section{Social:}

Social Reporting, Labor Practices, Human Capital, Talent Attraction and Retention, Citizenship and Philanthropy, Health and Safety, Advertising ethics, Editorial policy and Stakeholder Engagement . 


\section{Sustainability in Hotels}

$\mathrm{Hu}$ and Quan (2005) demonstrated that in order to measure the impacts of technology system on hotels' performance, the resource-based view (RBV) is required. The [RBV] links the performance of organizations to resources and skills that are firm specific, rare, and difficult to imitate or substitute in order to improve firm efficiency, effectiveness and create competitive advantage. Melville, Kraemer and Gurbaxani (2004) classified the performance into business process performance and organizational performance.

Ray et al., (2005) pointed that many organizations adopt sophisticated technology system to improve their performance. They also thought that technology system is used as a means to increase productivity, reduce costs, enhance the organization's competitive advantage, improve service quality and improve decision-making quality.

Performance management is directing and supporting employees to work as effectively and efficiently as possible in line with the needs of the organization. Furthermore, the performance management is to achieve high performance organization employees, and by "high performance" they mean reaching goals such as speed and quality of customer service, amount of productivity, profits and other targets, (Armstrong and Baron 2005).

Gallivan et al., (2005) identified other two constraints of technology system training: (1) it is often the first expense cut when corporations need to tighten their spending and (2) managers often perceive technology system training to be a solution that will increase user acceptance and usage of technology system, although there may be other nontraining barriers to technology system usage.

\section{Benefits of Sustainability}

Sustainability can help the market belter achieve full cost accounting in the pricing mechanism and voluntary sustainability standards can facilitate investment in sustainable technologies and practices. Another benefits of teaching sustainability is that it facilitates debate allows students to critically from their own opinion (Sloan, 2013).

In addition, (Heizer and Render, 2014) add other benefits that are:

- Positive public image, reduced liability

- Good systematic approach to pollution prevention

- Compliance with regulatory requirements, opportunities for competitive advantage

- Reduction in the need for multiple audits

Finally, market-based instruments, including voluntary sustainability standards, have the advantage of allowing market actors to select their level of adoption of sustainable practices based on the relative costs (efficiencies) with which they are able to do so (Potts et al., 2014).

\section{Technology System Components for Hotels}

Several researchers (e.g. O'Connor, 2004; Greaslyet al., 2006; Tesone, 2007; Turban, 2008) agreed that computer-based information system is made up of several components, including hardware, software, data communication, procedures and people. Tesone (2007) argued that some examples from the hospitality industry are reservation systems, property management systems, recipe-costing systems and conference and banqueting systems. Sometimes, specialized pieces of hardware are combined with software to automate a particular function. And there are some examples of such systems from the hospitality 
industry are call accounting systems, electronic point-of-sale systems, mini-bar systems and electronic door-lock systems.

In addition, Turban et al., (2008) indicated that data communication systems require the variety of software needed by any hardware configuration, plus such special software as communications programs. On the other hand, miller et al.,(2007) said that these components are used to process service area transactions and to capture data which are stored and later processed into timely reports for management. O'Connor (2009) mentioned that, these components work together to perform various tasks, each of them is independent, but is only productive when used with the other components. For example, hardware, the part of the computer that can physically see and touch, will be useless unless given instructions by the user through the software.

\section{Privileges of Applying IT in Hotels}

Sondara and Kahl, (2003) thought to eliminate pricing errors on guest checks, hotel computers automatically price menu, items, wines, and drinks. Servers can also use a price look up function. The computer does all the computations on the guest check, thereby eliminating error in pricing, addition, tax calculation, discounts, and totals. Gratzer and Winiwater (2003) revealed that hotels generally view technology system as a key resource and critical in providing competitive advantage and positioning in the market place. Jones and Murphy (2004) argued that new technology systems change the economy and the way business is conducted in various forms. In particular, technology system forces hotels to find new ways to expand the markets in which compete, to attract and retain customers by designing products and services to their needs, and to restructure their business strategy to gain competitive advantage.

Advantages of computer, in hotels attracted several researchers (e.g. Sondra and Kahl, 2003; Turban, 2008; Kandampully, 2011). Agreed that the benefits of using technology systems in hotels are various and include performance improvements, employee productivity and efficiency, work effectiveness, improved service quality, improved decision making and increased revenues. Furthermore, O'Connor (2009) added the benefits of productivity, reduced costs and increased revenues. He illustrated the benefits of performance improvements, productivity and efficiency, improved decision making and reduced costs. Tesone (2007) demonstrated efficiency, reduced costs and improved service quality benefits. Kandampully (2011) only argued over the benefits of work effectiveness and improved service quality; similarly other researchers (eg. Sahadev and Islam, 2005; Varini and Murphy, 2005) stressed the efficiency and improved service quality benefits. To that end, Lam, Cho and Qu (2007) agreed on the benefits of productivity and improved service quality.

Dillon (2005) argued that a technology system has a few benefits on its own. But most technology system benefits are derived from employees training and educational programs besides providing suitable organizational environment. Sondra and Kahl (2003) demonstrated that hotels can obtain benefits from technology system, for example, efficiency gains (e.g. the automation of clerical procedures), increased management effectiveness (e.g. in decision-making) and improved business performance (e.g. by entering into strategic alliances with other firms).

Several researchers (e.g. Kasavana, 2005; Walker, 2008; Kandampully, 2011) agreed that technology system helped hotels to reach one of their main goals which is to deliver 
exceptional guest satisfaction. Also using technology system helps the hotels to enhance service quality and enables customer to have a better experience by saving their time, enabling them to stay in touch with their world, offering convenience for them, and providing some modern entertainments. Kimes (2009) stated that achieving customer satisfaction leads to customer loyalty and sales maximization. Customer loyalty has been described as a concept of repeat purchase behavior.

\section{Information Technology practices in hotels:}

Regarding hotel management alert system, walker (2008) stated that [MICROS Alert Manager] allows operations to manage by exception. The system monitors conditions and compares them to established standards. Exceptions are immediately identified, and a notice or alert is sent to the pager, cell phone, or e-mail of those who need to know. The [MICROS Alert Manager] provides exciting new integration with the [RES] products and the on premise paging and communication solutions.

Many hotels have invested heavily in information technology (IT) infrastructure and networking that deploy the latest technical advances in their operations. Hospitality Industry strongly invested in information technology (IT) to generate new technologies in hotel departments. New technologies like Wi-Fi (wireless fidelity), radio frequency identification, GPS (global positioning system), VOIP (voice over internet protocol), hand held communication devices and WLAN (Wireless local area networks) are developing rapidly. Many types of software having comprehensive hotel applications are being used today in the hotels. With the help of technology customers involvement in service delivery has been increased (Singh, 2014)

First Practice: IT in Hotels Training. McAdams (2006) indicated that technology determinism represents an extreme view that ponders the possibility that someday humans will be servants to technology practitioners. He wonders whether the vast array of electronic data (largely unorganized for decision making) will ultimately cause more confusion than assistance for the modern knowledge worker. The possibilities created by technology have also introduced new dangers and ethical issues such as identity theft and guest privacy aggression that could lead to customer loss.

The benefits include recruiting more staff, allocating more training budget developing a training manual; conducting practical training regularly providing scheduled training, conducting short-take training for a longer period of time, applying different training methods, using visual procedure and posters and evaluating and reviewing the training regularly (Gad, 2010).

Human Resources better have a strong focus in fostering creative training and work for hotel employees through research of the best practices of the industry and adopting sustainable practices to encompass all stakeholders in their decision making process implement training and programs that consider the local community and environment through:

- Environmental education and ecological training for staff

- Excursions into the local community

- Hiring members of the host community

- Provides framework to benchmark social performance

- Measures and monitors performance to achieve ccertification 
- Performances based on sustainable social activity and social outcomes for tourism operations.

- Communicates their goals to employees, customers and suppliers of products and services to the organization (Riu Hotels and Resorts, 2014).

Second Practice: IT and Education for Sustainable Development. Education is critical for promoting sustainability and improving theability of people to address business issues in the context of the environment and society. Education is also critical to achieving environmental and ethical awareness and behavior consistent with sustainable business development and for responsible decision making (Sloan, 2013).

Education for sustainable development is the process of equipping trainees with the knowledge and understanding, skills and attributes needed to work and live in a way that safeguards environmental, social and economic wellbeing both in the present and for future generations (Longhurst, 2014). It means also working with trainees to encourage them to:

- Consider what the concept of global citizenship means in the context of their own discipline and in their future professional and personal lives.

- Consider what the concept of environmental stewardship means in the context of their own discipline and in their future professional and personal lives.

- Think about issues of social justice, ethics and wellbeing, and how these relate to ecological and economic factors.

- Develop a future-facing outlook; learning to think about the consequences of actions, and how systems and societies can be adapted to ensure sustainable futures (Longhurst, 2014).

Furthermore, there are four major methods according to (Hopkins, 2014) that support the education sustainability and IT as follows;

1. Public awareness and understanding.

2. Access to quality basic education.

3. Reorienting existing education.

4. Training programs for all sectors.

Third practice: IT in Hotel Marketing. Information technology could be applied to hotel marketing department on the following:

- Marketing Process - 'analysis, planning, implementation, and control' of marketing.

- Analyzing- Society becoming more environmentally friendly.

- New environmental practices lead to larger market share.

- Product differentiation.

- Partnerships: Environmental agencies (ex. Eco-club).

- Promotion through internet sites: Expedia and Google.

- Television ads.

- Promotions for environmental programs within the hotel.

- Promoting environmental programs on the website.

- Pamphlets inside each of the rooms (Riu Hotels and Resorts, 2014).

IV IT Practices in: Online Marketing and Paperless Billing. Eliminating paper bills is an obvious way to cut costs and ease the strain on the environment. The financial, telecommunications, public utility, insurance, healthcare and retail industries have led this trend, which reduces logging, paper processing and the fuel consumption associated with transporting bills and payments (Jones, 2009). Using information for supporting strategic 
market analysis including, targeting new customers, fine tuning loyalty programs, sales analysis and conducting trend analysis (Griffin, 1998). Having identified six is essential factors that can help build successful marketing strategies through the use of data mining, a statistical technique that builds models from vast data bases. They include, (a) creating direct mail campaigns, (b) planning seasonal promotions, (c) planning the timing and placement of ad campaigns, (d) create personal advertisements, (e) define growing and emerging markets, (f) help in room reservations (wholesale and business customers) (Magniniet al., 2003). The factors are recommended to be used in conjunction with other statistical modeling tools and help build competitive advantage (Magnini, et al. 2003).Property management system enabled to get guest information such as newspaper preference, wake up time, overnight laundry service, restaurants with distance and directions from hotel as well as many other options (Koutroumanis, 2011).

\section{Methodology}

Research Variables: The dependent variable of this study is represented by the ability of Egyptian five star Luxor hotels to successfully implement information technology. The independent variables of research are represented by hotels independent variables. That include

a) The size of hotels in terms of number of rooms available.

b) The number of all seniors' staff and managers that are deal with information technology.

c) The hotel's ability to purchase appropriate IT programs that help in practicing staff in different department.

d) The hotel's management commitment to use new technologies.

\section{Research Hypotheses:}

H1: Applying the information technology in Luxor five star hotels positively influences the hotel performance.

H2: Adapting appropriate system of information technology positively influences hotel sustainability.

H3: Bringing IT practices especially in: training, marketing and staff education positively influences hotel performance that keep the hotel sustained. The following figure illustrates that: 


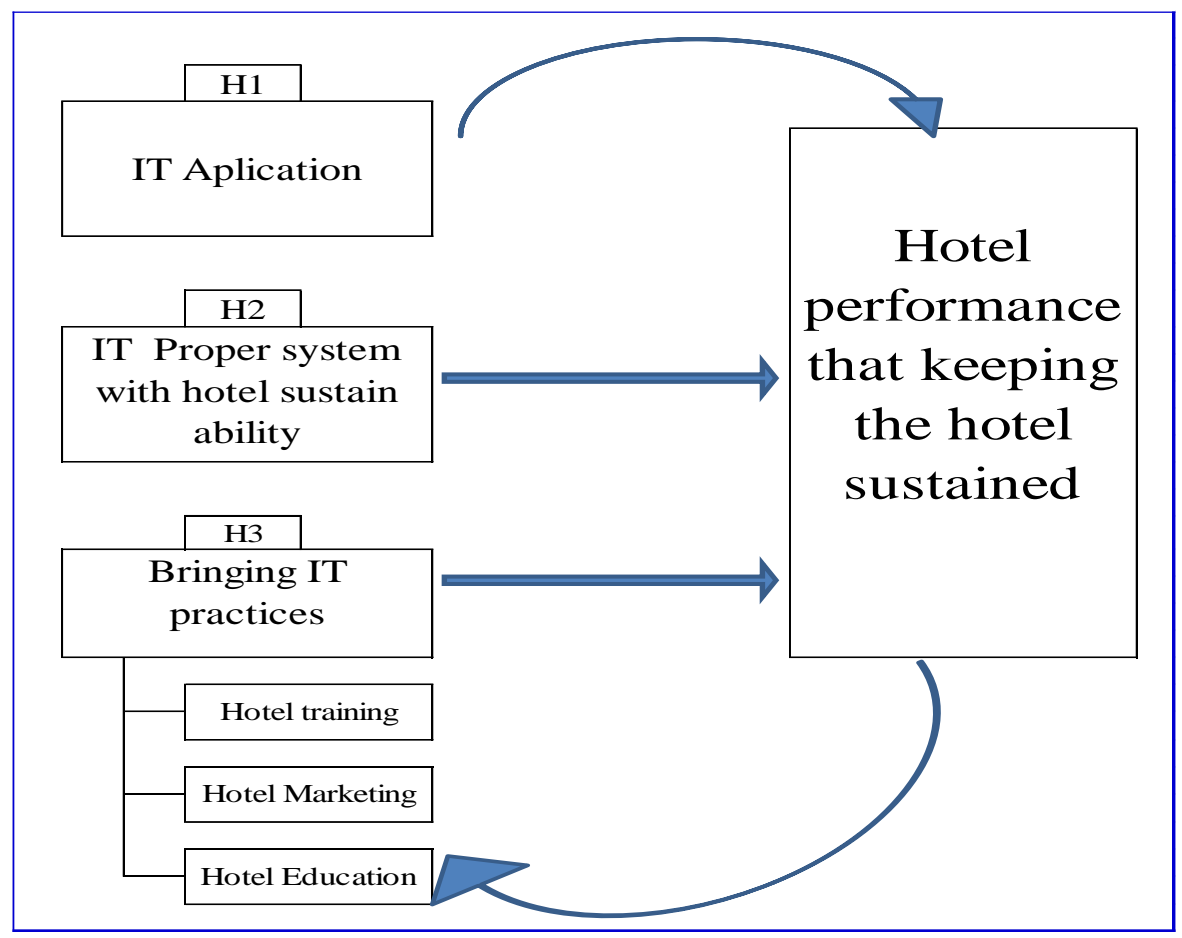

Figure 1: A conceptual model of IT, Business sustainability and hotel performance

\section{Data Analysis}

Accordingly to the data collected from questionnaire form, it's statistically and analyzed by using the statistical package per social science (SPSS V. 17.0). The mean and standard deviation have been calculated to classify the sets and determine how homogenous or in consistent the sample is regards to all study variables.

The data was collected through both of questionnaire with seniors managers in the whole different departments of Luxor five star hotels which are (7) hotels in the period of August 2014 till October 2014, and also a semi structured interview with the same seniors and juniors staff of a specific departments such as: training, marketing, front office and IT departments. There two tools were used to create the best practice on how the use of IT programs effect of hotel performance that lead to hotel sustainability.

Questionnaire and data collection: The study was conducted on a sample of seven brand five star hotels in Luxor that operate globally. The chosen of only five star hotels was due to the rise of their awareness level. The hotels samples are as follows in table (1) 


\begin{tabular}{|c|c|c|c|c|c|}
\hline \multicolumn{6}{|c|}{ Table (1) The Sample Population } \\
\hline No. & Hotel Name & 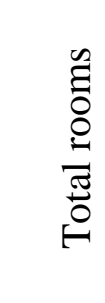 & 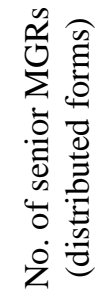 & 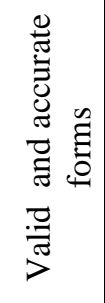 & $\%$ \\
\hline 1. & HILTON LUXOR HOTEL \& SPA & 374 & 25 & 20 & 80 \\
\hline 2. & LUXOR SHERATON HOTEL \& RESORT & 580 & 55 & 50 & 90 \\
\hline 3. & $\begin{array}{l}\text { MARITIM JOLIE VILLE KINGS ISLAND } \\
\text { RESORT }\end{array}$ & 685 & 60 & 50 & 83 \\
\hline 4. & SOFITEL KARNAK HOTEL & 600 & 55 & 50 & 90 \\
\hline 5. & SOFITEL WINTER PALACE HOTEL & 468 & 50 & 40 & 80 \\
\hline 6. & SONESTA ST. GEORGE HOTEL LUXOR & 559 & 50 & 40 & 80 \\
\hline 7. & $\begin{array}{l}\text { STEIGENBERGER NILE PALACE } \\
\text { HOTEL }\end{array}$ & 482 & 50 & 40 & 80 \\
\hline & Total & & 345 & 290 & $84 \%$ \\
\hline
\end{tabular}

\section{Results and Discussion}

The responses obtained from the directed questionnaires are shown as follows:

Study Instrument reliability. For all scales, Cranach alpha correlation coefficient was calculated to determine the internal consistency of the scale, Reliability coefficient of 0.70 or higher is considered "acceptable" in most social science situations.

The Cranach Alpha reliability was computed and the tests showed that the reliability coefficients for all the instruments were above 0.70 , which indicates that the instrument is reliable for being used. Cronbach alpha for all five survey instruments is shown in the following table:

\begin{tabular}{|c|c|}
\hline \multicolumn{2}{|l|}{ Table (2) Reliability Statistics } \\
\hline Cronbach's Alpha & No. of Items \\
\hline .765 & 26 \\
\hline
\end{tabular}

Demographic data analysis: This information was useful in understanding the nature of Luxor hotels staff profiles. Results are presented in table (3).

\begin{tabular}{|c|c|c|}
\hline \multicolumn{3}{|c|}{ Table (3) Luxor hotels staff profile analysis } \\
\hline Demographic data & Freq & $\%$ \\
\hline \multicolumn{3}{|l|}{ Origin place } \\
\hline a. Cairo & 70 & $24 \%$ \\
\hline b. Luxor & 180 & $62 \%$ \\
\hline b. Others & 40 & $14 \%$ \\
\hline Total & 290 & 100 \\
\hline 2. Gender & & \\
\hline
\end{tabular}




\begin{tabular}{|c|l|l|}
\hline \multicolumn{1}{|c|}{ a. Male } & $\mathbf{2 7 0}$ & $\mathbf{9 3 \%}$ \\
\hline b. Female & 20 & $7 \%$ \\
\hline Total & 290 & 100 \\
\hline 3. Age & & \\
\hline a. Under 20 years old & 20 & $7 \%$ \\
\hline b. From 20 to 40 years & $\mathbf{1 8 0}$ & $\mathbf{6 2 \%}$ \\
\hline c. Over 40 years & 90 & $31 \%$ \\
\hline Total & 290 & 100 \\
\hline 4. Educational Level & & \\
\hline a. Technical school & 30 & $10 \%$ \\
\hline b. University or higher education & $\mathbf{2 2 0}$ & $\mathbf{7 6 \%}$ \\
\hline c. Post graduates studies & 30 & $10 \%$ \\
\hline d. Others & 10 & $4 \%$ \\
\hline Total & 290 & 100 \\
\hline
\end{tabular}

Data indicated that most of the respondents were from Luxor (62\%) that means, it will be easier to learn the IT technologies to the hotel staff who are Luxor citizens. In addition to their turnover could be decreased and their hotel stability could be increased since they are from the same town.

Data showed also, that the majority of five star Luxor hotels are males (93\%) due to the town habits and traditions. Concerning the ages (62\%) of the respondents were from (20) to (40) years old indicated that, they are youth and can get easily any educated training or IT skills. Finally, most of them were having university degree (76\%), that referred to they have the ability to learn what keeps the hotel sustained.

Results analysis: The total numbers of questionnaire sample distributed through (hotels, hotels mails and hotels social media networks) were (360), only (290) samples were correctly received and ready to be analyzed.

The following table illustrates the means and standard deviations of the factors: 


\section{Table (4) Results of Applying IT to Hotel Performance in Luxor Five Star Hotels}

\begin{tabular}{|c|c|c|c|c|c|c|c|c|c|c|c|c|c|}
\hline \multicolumn{14}{|c|}{ Table (4) Results of Applying IT to Hotel Performance in Luxor Five Star Hotels } \\
\hline \multirow{2}{*}{$\dot{0}$} & \multirow[t]{2}{*}{ Scale Item } & \multicolumn{2}{|c|}{$\begin{array}{l}\text { Strongly } \\
\text { disagree }\end{array}$} & \multicolumn{2}{|c|}{ Disagree } & \multicolumn{2}{|c|}{ Neutral } & \multicolumn{2}{|c|}{ Agree } & \multicolumn{2}{|c|}{$\begin{array}{l}\text { Strongly } \\
\text { agree }\end{array}$} & \multirow[t]{2}{*}{ Mean } & \multirow{2}{*}{$\begin{array}{c}\text { Std. } \\
\text { Deviatio } \\
\mathrm{n}\end{array}$} \\
\hline & & Freq & $\%$ & Freq & $\%$ & Freq & $\%$ & Freq & $\%$ & Freq & $\%$ & & \\
\hline 1 & $\begin{array}{l}\text { The hotel using multiple IT applications of soft } \\
\text { and hard wares for hotel services. }\end{array}$ & 10 & 3 & 20 & 7 & 150 & 52 & 90 & 31 & 20 & 7 & 3.3103 & .83618 \\
\hline 2 & $\begin{array}{l}\text { The IT program used is totally appropriate } \\
\text { (proper) for the hotel facilities. }\end{array}$ & 25 & 9 & 145 & 50 & 50 & 17 & 30 & 10 & 40 & 14 & 2.7069 & 1.19121 \\
\hline 3 & $\begin{array}{l}\text { The hotel depends on international IT programs } \\
\text { design in offering the hotel services. }\end{array}$ & 90 & 31 & 100 & 35 & 50 & 17 & 50 & 17 & - & - & 2.2069 & 1.06467 \\
\hline 4 & $\begin{array}{l}\text { IT applications in some definite departments lead } \\
\text { to develop the hotel performance. }\end{array}$ & 50 & 17 & 50 & 17 & 10 & 3 & 100 & 35 & 80 & 28 & 3.3793 & 1.47444 \\
\hline 5 & $\begin{array}{l}\text { Hotel booking through the net and electronic } \\
\text { reservation increase the occupancy level. }\end{array}$ & 45 & 16 & 45 & 16 & 30 & 10 & 120 & 41 & 50 & 17 & 3.2931 & 1.34149 \\
\hline 6 & $\begin{array}{l}\text { The IT applications contribute in reducing hotel } \\
\text { expenses. }\end{array}$ & 40 & 14 & 40 & 14 & 90 & 31 & 100 & 35 & 20 & 7 & 3.0690 & 1.14460 \\
\hline 7 & $\begin{array}{l}\text { The actual cost of purchasing the IT programs is } \\
\text { considered not effective in expenses. }\end{array}$ & 25 & 9 & 45 & 16 & 70 & 24 & 100 & 35 & 50 & 17 & 3.3621 & 1.18669 \\
\hline 8 & $\begin{array}{l}\text { The hotel has the ability to financially accredit } \\
\text { new technological programs. }\end{array}$ & 40 & 14 & 50 & 17 & 40 & 14 & 120 & 41 & 40 & 14 & 3.2414 & 1.27947 \\
\hline 9 & $\begin{array}{l}\text { IT programs participates in increasing the flow of } \\
\text { hotel department information. }\end{array}$ & - & - & 30 & 10 & 50 & 17 & 110 & 38 & 100 & 35 & 3.9655 & .96595 \\
\hline 10 & $\begin{array}{l}\text { Using IT applications increase hotel transparency } \\
\text { and decrease the decay. }\end{array}$ & - & - & 40 & 17 & 50 & 17 & 100 & 35 & 100 & 35 & 3.8966 & 1.03050 \\
\hline 11 & $\begin{array}{l}\text { Using IT applications give trust between the staff } \\
\text { and hotel management. }\end{array}$ & - & - & 20 & 6 & 70 & 24 & 100 & 35 & 100 & 35 & 3.9655 & .92944 \\
\hline 12 & $\begin{array}{l}\text { Using IT helps in achieving hotel competitive } \\
\text { edge }\end{array}$ & 10 & 3 & 40 & 14 & 100 & 35 & 70 & 24 & 70 & 24 & 3.5172 & 1.10428 \\
\hline 13 & IT applications help in avoid human errors. & - & - & 20 & 7 & 50 & 17 & 100 & 35 & 120 & 41 & 4.1034 & .92429 \\
\hline
\end{tabular}


Table (4) lists the mean scores of the different categories of IT applications and hotel performance, the results showed that more than half of the samples $(52 \%)$ were neutral in using multiple soft and hard wares in the hotel services, indicated that most of Luxor hotels didn't deals with IT programs on a regular base. With a mean (3.3103) and std. deviation (.83618) which is less than one in comparison with other variables.

Item no. 2, was aimed to know if the IT programs was used for all the hotel facilities, results showed that half of the sample $(50 \%)$ was not deal with those programs indicates that, there is a lack in offering IT programs that raise the hotel performance, with a mean ( 2.27) and std. deviation (1.2).

Item no. 3, It was used to examine if the Luxor hotels depending on international IT programs or not, results showed that $(31 \%)$ weren't strongly disagree indicate that, there is no international programs used that help in promotion the hotel performance, with a mean (2.21) and std. deviation (1.1).

Item no.4, the results showed that (34\%) of respondents were agreed that IT application in some definite departments lead to develop the hotel performance that assured increasing in hotel performance, with a mean (3.33) and std. deviation (1.5).

Item no.5, assured that (41.4\%) agreed then (17.2) strongly agreed about the occupancy level through booking the net that increase automatically the hotel performance, with a mean ( 3.3 ) and std. deviation (1.3).

Item no.6, showed that $(34.5 \%)$ were neutral while also the same ration was given to agree, that means IT programs is reducing expenses, with M (3.1) and SD (1.4).

Item no.7, showed that (35\%) of the sample were neutral, and also agreed about the actual cost of purchasing IT programs is reducing expenses, with a mean (3.4) and std. deviation (1.2).

Item no.8, showed that $(41.4 \%)$ of the sample were neutral and agreed also with the same ratio (41.4) about the hotel ability to buy new technological programs that help in increasing the level of hotel performance, with M (3.2) and SD (1.3).

Item no.9; indicate that neutral and agreed were repeated twice with the same ratio $(37.5 \%)$ concerning the participation of IT programs in increasing the hotel flow with a mean (4) and std. deviation (1).

Item no.10, showed that most of the respondents were referred to natural, agree and strongly agree, with the same ratio (35\%) to everyone, assured that IT applications are really increased the hotel transparency and decreased the decays. with a mean (3.9) and std. deviation (1.0).

Item no.11, reflected both of agreed and strongly agreed with a ratio (35\%) to each one assured that the majority of the total sample were agreed about using the IT applications that give trust between staff and hotel management that increase hotel performance with a mean almost (4) and std. deviation (1).

Item no. 12 , showed that $(34.5 \%)$ of the total sample were natural about using the IT in helping in achieving a competitive edge with $\mathrm{M}$ (3.5) and SD (1.1).

Finally, concerning Item no.13, it was found that $(41.4 \%)$ of the sample were strongly agree about that IT applications help in avoiding any human errors which increase the hotel performance with a mean (4.1) and std. deviation (1.0). 
The following table focuses on the relation between applying IT through bringing practices to get the hotel sustained:

\begin{tabular}{|c|c|c|c|c|c|c|c|c|c|c|c|c|c|}
\hline \multicolumn{14}{|c|}{ Table (5) the results of analysis of IT and hotel sustainability "through bringing practices" } \\
\hline \multirow{2}{*}{$\dot{2}$} & \multirow[t]{2}{*}{ Scale Item } & \multicolumn{2}{|c|}{$\begin{array}{l}\text { Strongly } \\
\text { disagree }\end{array}$} & \multicolumn{2}{|c|}{ Disagree } & \multicolumn{2}{|c|}{ Neutral } & \multicolumn{2}{|c|}{ Agree } & \multicolumn{2}{|c|}{$\begin{array}{l}\text { Strongly } \\
\text { agree }\end{array}$} & \multirow[t]{2}{*}{ Mean } & \multirow{2}{*}{$\begin{array}{c}\text { Std. } \\
\text { Deviation }\end{array}$} \\
\hline & & Freq & $\%$ & Freq & $\%$ & Freq & $\%$ & Freq & $\%$ & Freq & $\%$ & & \\
\hline 2 & The hotel benefits from IT programs in staff training. & 30 & 10 & 100 & 35 & 50 & 17 & 50 & 17 & 60 & 21 & 3.0345 & 1.32797 \\
\hline 3 & The hotel benefits from IT programs hotel marketing. & - & - & 100 & 35 & 10 & 3 & 90 & 31 & 90 & 31 & 3.5862 & 1.24831 \\
\hline 5 & $\begin{array}{l}\text { IT programs supply hotels with vital rules that could be } \\
\text { sustained in hotel development business. }\end{array}$ & - & - & 40 & 13 & 60 & 21 & 90 & 31 & 100 & 35 & 3.8621 & 1.04316 \\
\hline 6 & $\begin{array}{l}\text { The hotel employs qualified staffs that have the ability } \\
\text { in using IT. }\end{array}$ & 40 & 14 & 50 & 17 & 50 & 17 & 100 & 35 & 50 & 17 & 3.2414 & 1.30623 \\
\hline 7 & $\begin{array}{l}\text { The hotel offered IT training programs courses to all } \\
\text { the hotel staff to develop their skills. }\end{array}$ & 60 & 21 & 110 & 38 & 20 & 7 & 50 & 17 & 50 & 17 & 2.7241 & 1.41413 \\
\hline 8 & $\begin{array}{l}\text { The hotel uses the full application of IT in the whole } \\
\text { hotel department. }\end{array}$ & 90 & 31 & 90 & 31 & 50 & 17 & 50 & 17 & 10 & 4 & 2.5862 & 1.50011 \\
\hline 10 & $\begin{array}{l}\text { The hotel always redevelops and recharges the IT } \\
\text { programming and buy new ones. }\end{array}$ & 50 & 17 & 100 & 35 & 50 & 17 & 50 & 17 & 40 & 14 & 2.9310 & 1.25973 \\
\hline 11 & $\begin{array}{l}\text { IT contributes in utilization the hotel resources in better } \\
\text { way. }\end{array}$ & - & - & 20 & 7 & 50 & 17 & 130 & 45 & 90 & 31 & 3.8966 & .99635 \\
\hline 12 & IT helps in avoiding hotel failure and slowness. & - & - & 30 & 10 & 60 & 21 & 90 & 31 & 110 & 38 & 3.9655 & 1.00113 \\
\hline 13 & $\begin{array}{l}\text { I agree that bringing IT programs in specific area like } \\
\text { hotel training, marketing and staff education lead to } \\
\text { hotel sustainability that keeps performance. }\end{array}$ & - & - & 20 & 7 & 50 & 17 & 100 & 35 & 120 & 41 & 4.1034 & .92429 \\
\hline
\end{tabular}


Table (5) shows in item (1) that (38\%) of the respondents disagreed that hotel benefits from IT programs in planning and setting reports that indicates there is no awareness or knowledge about the importance of using these programs in long planning that keep the hotel sustained, with $\mathrm{SD}(1.0813)$ and $\mathrm{M}$ (2.28).

Concerning the benefits of IT programs in staff training, results showed that $(35 \%)$ of the senior managers were disagreed about these benefits, indicated that, they hadn't these programs and didn't know how importance are they, SD (1.327) and $\mathrm{m}$ (3.034).

Regarding the benefits of IT programs and how to use it in hotel marketing, (35\%) of the respondents were disagree about its importantly in all types of marketing that keeping the hotel sustained and increase its performance, SD (1.248) and M was (3.59).

In item no. (4). about (38\%) of the respondents disagreed that whether they can benefit from the IT programs in educating the staff that leads to decrease in their performance, SD was (1.449) and M(3.207).

Item no. (5). Referred to (35\%) of the respondents were strongly agreed that IT programs supply hotels with important rules that keep the hotel developed. Means they have awareness and convenience of that. SD (1.043) and M was (3.862).

Concerning hiring qualified staff that how to use techniques IT technique, $(35 \%)$ of them were agreed that they already employed these skilled people that use easily any IT technique, with $\mathrm{SD}(1.306)$ and $\mathrm{M}$ (3.241).

In item no 7, (38\%) of the respondents refused that the hotel offered any kind of IT training programs. that Increase their performance, and they only offered other training programs just related to service, SD was (1.414) and M (2.724).

About (62\%) of the respondents were strongly disagree and disagree in using the IT applications in the whole hotel departments, indicated that there is a lack in applying this system at all that lead to decrease the hotel performance. M was (2.586) and SD (1.500).

In item no (9), (35\%) of the respondents disagree that the hotel didn't offered any additional services among the hotel departments with only one data base, that leads to not accuracy and failed in performance in general. with $\mathrm{M}$ (2.655) and SD was (1.495).

Concerning redevelopingandrecharging the IT programs and always buying new ones, results showed that $(35 \%)$ of the respondents disagreed about that means, they hadn't any system for buying IT programs or even updating them.

Item no.(11) Referred to (45\%) of the sample agreed that IT contributes in utilizing the hotel resources in a better way which means they have the awareness of the IT importance. M was (3.897) and SD (.996).

In item no (12), (38\%) of the senior managers of Luxor five star hotels were strongly agreed that IT helps in avoiding hotel failure and slowness with SD (1.001) and M (3.965) that in turns increase performance.

Finally, (41\%) of the respondents were also strongly agreed about bringing IT programs especially in hotel training, marketing and staff education that lead to raise the hotel performance and keep the hotel sustained . M was (4.163) and SD was (.924).

Research hypotheses were tested using Pearson correlation coefficient. Preliminary analyses were performed to ensure no violation of assumptions of normality and linearity. Table (6) shows that there are strong correlations between all proposed relation in the conceptual hypotheses, with $(\mathrm{r})$ values ranging from $(.423)$ to $(.837)(\mathrm{p}<.005)$ and the obtained correlation values are in the expected positive direction. Based on the results of 
Pearson correlation analysis which represent proposed linear relationship, all the research hypotheses were fully supported, the following table illustrates that:

Table (6) is summary of correlation analysis and hypotheses testing.

\begin{tabular}{|l|l|l|}
\hline \multicolumn{1}{|c|}{ Hypothesized Correlation } & \multicolumn{1}{|c|}{$\begin{array}{c}\text { Pearson } \\
\text { correlation(r) }\end{array}$} & Hypotheses \\
\hline H1: Applying IT with hotel performance & $.837^{* *}$ & Supported \\
\hline H2: Adopting IT system and keeping the hotel sustained & $.423^{* *}$ & Supported \\
\hline $\begin{array}{l}\text { H3: Bringing IT practices that keep the hotel sustained and } \\
\text { improve performance }\end{array}$ & $.702^{* *}$ & Supported \\
\hline
\end{tabular}

Note $* *$ correlation is significant at the 0.001 level.

\section{Conclusion}

After analyzing data it was found the following:

- Luxor hotels didn't use any practices of information technology unless using it as a software system in checking in, out and marketing.

- Most of the head departments were convinced that, there is a significant relation between the information technology practices and keeping their hotel business sustained.

- Using of good practices of IT especially in training, marketing and staff education lead to reduction in expenses and increase revenue, as well as increasing quality of service provided to customers that assured stability in hotel performance.

- There is a significant difference between IT applications and the hotel performance in the investigated Luxor five star hotels that means technological abilities and capabilities of these hotels are not the same and the human resources needs to be more flexible, to keep its sustainability.

- Management department IT programs impact on hotel performance that gives the work a lot of velocity and flexibility which affect the work completed successfully and keep it always sustained.

- There is no significant difference found between employee's confidence of front office, marketing and training" and information technology application.

- There is a relation between application of information technology and the level of keeping the service returns back.

- Finally, there is a significant relationship between programs application of information technology in all hotel departments and hotel sustainability through stability in performance.

\section{Recommendations}

The following recommendations are based on the findings and discussions of the results in this study:

- Hotels should bring new practices that help in increasing its performance and keeping the business sustained. These practices should focus on three areas in hotels that are: marketing, training and staff education. 
- Both of marketing and training managers should rely on applying the IT programs on its marketing plans and campaigns to improve the hotel performance that keep the hotel sustained.

- Hotels should use more updated software programs in different departments with qualified and well educated staff that achieved sustainability.

- Creating an integrated internal system among the hotel departments through applying the IT programs that keep the hotels sustained.

- Hotels should select qualified, experience and well educated employees, to keep them sustained with high performance.

- Business ethics plays a fundamental part in any hotel sustainability therefore; recent hired staff should learn the meaning of their behaviors.

- Finally, hotels managers have to know that excellence in their performance requires essentials elements such as; strategic management, transparency, accountability and performance evaluation, and all of that assuring sustainability.

\section{References}

- Armstrong, M., and Baron, A. (2005. "Managing Performance: Performance Management in Action, P 2.

- Ball , A . (2014). Ball Corporation 2014 Sustainability Report, Ball Corporation, pp.5-19, Available from "www.ball.com/sustainability", (Accessed 19 December 2014).

- Bomba, O. (2014).Corporate Sustainability, IHS Inc. Available from"jane.bomba@ihs.com", (Accessed 14 December 2014).

- Chathoth, P. (2007). The Impact of Information Technology on Hotel Operations, Service Management and Transaction Costs: A Conceptual Framework for Full-Service Hotel Firms. International Journal of Hospitality Management, 26 (4), pp.395-408.

- Edward, J. L, (2007). The Role of Information Technology in Quality Management Implementation and Its Impact on Organizational Performance: An Analysis of U.S Telecommunication Organization, Retrieved May 20, 2011 from Pro Quest Digital Dissertations Database: http//www.ProQuest.com.

- Gad, T. (2010). The Impact of Information Technology on Human Element in Hotel Industry. Unpublished research, PhD Dissertation. Faculty of Tourism and Hotel Management, Helwan University.

- Gallivan, M., Spitler, V. and Koufaris, M. (2005). Does Information Technology Training Really Matter? A Social Information Processing Analysis of Coworkers' Influence on IT Usage in the Workplace. Journal of Management Information Systems, 22 (1), pp. 146-162.

- Gratzer, M. and Winiwater, W. (2003).A Framework for Competitive Advantage in Tourism. Austria, ECommerce Competence Centre.

- Greasley, A.' Bocij, P.; Chaffey, D.; Hickie, S. (2006). "Business Information Systems: Technology, Development and Management for the E-Business". Third Edition. New York, Prentice Hall, p. 565.

- Griffin, R. (1998). Data Warehousing: The Latest Weapon for the Lodging Industry? Cornell Hotel and Restaurant Administration Quarterly, 39, (4), 28-46.

- Heizer and Render, (2014).Sustainability in the Supply Chain, SUPPLEMENT 5, PowerPoint Presentation to Accompany, Operations Management, Eleventh Edition

- Principles of Operations Management, Ninth Edition, PowerPoint slides by Jeff Heyl.@ 2014 Pearson Education, Inc.Available from "hr_om11_ch05s.ppt", (Accessed 11 December 2014).

- Hopkins, C. (2014). The Role of Education in the Pursuit of a Sustainable Future, LSF AGM, UNESCO and UNU Chairs, York University, Available from"www.unesco.org/education/tlsf", ", (Accessed 15 December 2014).

- Hu, Q. and Quan, J. (2005). Evaluating the Impact of IT Investments on Productivity: A Casual Analysis at Industry Level. International Journal of Information Management, 25 (1), pp.31-55.

- Jones, E. and Murphy, H. (2004). Stakeholder Perspectives in the Adoption of Information And Communication Technologies In Small And Medium Enterprises For Intelligent Destination Development: The Case of Wales. Journal of Economic Perspectives, 14 (4), pp.1-53.

- Jones, T. (2009).IT and sustainability: Bringing best practices to the business. A report from the Economist Intelligence Unit Sponsored by Oracle .pp. 2-10. 
- Kandampully, A. J. (2011). Service Management: The new Paradigm in Hospitality, New Jersey, Pearson Prentice Hall, pp.312-330.

- Kimes, S.E. (2009). The Role of Technology in Restaurant Revenue Management". Cornell Hospitality Quarterly 49(3): 297-309.

- Koutroumanis, A (2011).Technology's Effect on Hotels and Restaurants: Building a Strategic Competitive Advantage. University of Tampa. Journal of Applied Business and Economics vol. 12(1) .pp.72-79.

- Lee, K., Chung, N. and Kim, J. (2006). Analysis of Decision-Making Performance from a Schemata Approach to Cognitive Resonance [Internet], pp.459-466.Available from:"http://s-cahvishnu.infotech.monash.ed 2004/proceedings/pdf/45_Lee_Chung_Kim.pdf".(Accessed 25 June 2014).

- Longhurst, J. (2014). Education for Sustainable Development: Guidance for UK Higher Education Providers, University of the West of England, Chair, QAA/HEA Education for sustainable development group, pp.5-21. Available from: "Education-sustainable-development-Guidance-June-14.pdf", (Accessed 22 December 2014).

- Magnini, V., Honeycutt, E., \& Hodge, K. (2003). Data Mining for Hotel Firms: Use and Limitations. Cornell Hotel and Restaurant Administration Quarterly, 44, (2), 94-105.

- Miller, J.; Dopson, L.; Hayes, D. (2006). "Food and Beverage Cost Control". Fourth Edition, New Jersey, John Wiley and Sons, Inc., pp. 484-494.

- O'Connor, P. (2004). Using Computers In Hospitality. Second Edition., New York, Continuum, PP. $229-286$.

- O'Connor, P. (2009). Pay-per-Click Search Engine Advertising: is Hotel Trademarks Being Abused?" Cornell Hospitality Quarterly 50(2):pp. 232-44.

- Potts, J; Lynch, M; Wilkings, A; Huppé, G; Cunningham, M and Voora, V.(2014). The State of Sustainability, Initiatives Review 2014, Standards and the Green Economy, pp.5-22.

- Ray, G., Muhanna, W. and Barney, J. (2005). Information Technology and the Performance of the Customer Service Process: A Resource-Based Analysis. MIS Quarterly, 29 (2), pp.625-636.

- Riu Hotels and Resorts, (2014). Sustainable Solutions, Available from:"http

- "3P12 Presentation.ppt", (Accessed 21 May 2014).

- Sloan. P. (2013), "Sustainability in the Hospitality Industry", TJ International Ltd, Pad stow, Cornwall. PP. 350- 352.

- Singh, A. (2014). "Hotel Housekeeping Modern Practices, Challenges and Opportunities - an Appraisal", International Journal of Research in IT and Management", Volume 4, Issue 3, pp. 41-44. On line "http://www.euroasiapub.org"

- Singh, A. J., and Kasavana, M. L. (2005). The Impact of Information Technology on Future Management of Lodging Operations: A Delphi Study to Predict Key Technological Events in 2007 and 2027. Tourism and Hospitality Research, 6, 24-37.

- Sondra, D., Kahl, K. (2003). "Restaurant Service Basics". First edition, New York, John Wiley and Sons, Inc.

- Tesone, D. (2007). Hospitality Information Systems and E-Commerce.New Jersey, John Wiley and Sons, Inc. to IS group performance.MIS Quarterly, 20 (4), pp.410-425.

- Turban, E., Rainer, K. R., and Potter, E, R, (2008). Introduction to Information Technology, USA, John Wiley and Sons, Inc., PP.15-17.

- Varini, K. and Murphy, H. (2005).An Investigation of Expert Predictions of Profit Optimization Opportunities from Information Communication Technologies (ICTs) in the Hotel Sector.Springer Computer Science, 5 (2), pp.463-474.

- Walker, J. (2008). The Restaurant from Concept to Operation. Fifth edition. John Wiley and sons, inc. Hoboken, New Jersey.

- Zadlo, J and Gray,G.(2014). Using Information Technology for Competitive Advantage, MIS 480 Group Presentation, Available from: "Cafo 12[compatibility mode]microsoftpowerpoint.ppt", (Accessed 23 September 2014). 